\title{
The availability of lysine in diets for pigs: comparative methodology
}

\author{
BY JANE LEIBHOLZ \\ Department of Animal Science, University of Sydney, Camden, New South Wales 2570, Australia
}

(Received 19 January 1990 - Accepted 19 June 1991)

\begin{abstract}
Four experiments were conducted to compare different methods for estimating the availability of lysine in protein feeds. The same feeds were used in all experiments. In the first experiment the apparent digestibility of lysine to the ileum of growing pigs was found to be $0.92,0.69,0.73,0.85,0.84$ and 0.97 for soya-bean meal, cottonseed meal 1 , cottonseed meal 2 , meat meal, sunflower meal and skim milk respectively. In the second experiment the utilization of lysine (relative to free lysine) for weight gain, as measured in weaner pigs, was found to be $0.68,0.73,0.81,0.86$ and 1.00 for cottonseed meal 1 , cottonseed meal 2, meat meal, sunflower meal and skim milk respectively. In Expt 3 diets were formulated to contain soya-bean meal, sunflower meal or cottonseed meal 2 with the same available lysine content from the measurements made in Expts 1 and 2. The feed conversion ratios of weaner pigs given these diets were similar for the three sources of protein when the values were adjusted for the differences in digestible dry matter intake. In the fourth experiment isoenergetic and isonitrogenous diets were formulated with increasing amounts of lysine from synthetic lysine or cottonseed meal 2 . The diets were given to weaner pigs and resulted in a curvilinear response to lysine particularly for the cottonseed meal, so that the availability of lysine in cottonseed meal was similar to that of synthetic lysine at low lysine intakes and much lower than synthetic lysine at higher lysine intakes. Possible reasons for the curvilinear responses are discussed.
\end{abstract}

Lysine: Availability: Pigs

The determination of the availability of amino acids in diets for pigs has evoked considerable research. However, there is still much uncertainty about techniques suitable for the measurement of availability and the validity of the results from these methods.

Availability may be defined as the proportion of an amino acid in a feed that is in a form suitable for digestion and utilization by an animal. The utilization of an amino acid may vary with the other dietary ingredients and the physiological state of the animal. Utilization is usually measured by slope-ratio or regression assays using deficient diets. Different response curves have been obtained for similar feeds using weight gain, carcass gain, feed conversion ratio and nitrogen retention as the criteria of response (Batterham et al. 1979; Leibholz, 1986).

The apparent digestibility of amino acids to the end of the ileum can be measured (Leibholz \& Mollah, 1988), but it is probable that not all amino acids absorbed before the ileum are utilized with equal efficiency, hence a feeding trial incorporating the test amino acid in an amount according to its digestibility to the ileum should be conducted (Tanksley \& Knabe, 1984).

Lysine is usually the first limiting amino acid in diets for pigs. The present experiments were designed to determine the ileal digestibility of lysine and the availability of lysine in the same feedstuffs, and then to test these results in feeding trials. 
Table 1. Expt. 1. Composition of diets $(\mathrm{g} / \mathrm{kg})$

\begin{tabular}{|c|c|c|c|c|c|c|c|c|}
\hline Diet no.... & 1 & 2 & 3 & 4 & 5 & 6 & 7 & 8 \\
\hline Soya-bean meal & 255 & - & - & 一 & - & - & - & - \\
\hline Cottonseed meal 1 & 一 & 435 & - & - & - & - & - & - \\
\hline Cottonseed meal 2 & 一 & - & 430 & - & - & 一 & - & - \\
\hline Meat meal & 一 & 一 & - & 276 & - & - & - & - \\
\hline Sunflower meal & 一 & - & - & - & 598 & - & - & - \\
\hline Dried skim milk & - & - & - & - & - & 273 & - & - \\
\hline Wheat gluten & 一 & - & - & - & - & - & 465 & - \\
\hline Wheat & 一 & - & - & - & - & - & - & 895 \\
\hline Maize starch & 640 & 460 & 465 & 651 & 297 & 622 & 430 & - \\
\hline Sunflower oil & 20 & 20 & 20 & 20 & 20 & 20 & 20 & 20 \\
\hline Calcium stearate & 20 & 20 & 20 & 20 & 20 & 20 & 20 & 20 \\
\hline $\begin{array}{l}\text { Calcium dihydrogen } \\
\text { phosphate }\end{array}$ & 33 & 33 & 33 & - & 33 & 33 & 33 & 33 \\
\hline Premix* & 30 & 30 & 30 & 30 & 30 & 30 & 30 & 30 \\
\hline Tryptophan & - & - & - & $0 \cdot 7$ & - & - & - & - \\
\hline Methionine & 2 & 2 & 2 & 2 & 2 & 2 & 2 & 2 \\
\hline
\end{tabular}

* Vitamin and mineral supplement supplying ( $\mathrm{mg} / \mathrm{kg}$ diet) : potassium 2600 , sodium 2000 , magnesium 400 , iron 100 , zine 100 , manganese 10 , copper 10 , iodine $0 \cdot 1$, selenium $0 \cdot 1$, retinol $1 \cdot 5$, cholecalciferol $0 \cdot 025, \alpha$-tocopheryl acetate 10 , menadione 1 , biotin $0 \cdot 1$, choline 300 , folacin $0 \cdot 3$, niacin 15 , pantothenic acid 10 , riboflavin 3 , thiamine 1, pyridoxine 1, cyanocobalamin $10 \mu \mathrm{g}$, butylated hydroxytoluene 100 .

\section{MATERIALS AND METHODS \\ Expt 1}

Eight diets were prepared as shown in Table 1 . The lysine content of all diets was $8 \mathrm{~g} / \mathrm{kg}$. The diets were sprayed with an indigestible marker (ytterbium nitrate, at $100 \mathrm{mg} \mathrm{Yb} / \mathrm{kg}$ diet).

Six male Landrace $\times$ Large White pigs ( $25 \mathrm{~kg}$ initial live weight) were fitted with ' $\mathrm{T}$ 'shaped cannulas in the terminal ileum, $100 \mathrm{~mm}$ from the ileo-caecal junction. The pigs were housed in metabolism cages and fed continuously from belt feeders. Each pig was given $1.5 \mathrm{~kg}$ feed $/ \mathrm{d}$, and water was available $a d \mathrm{lib}$. from nipple drinkers. There were no feed residues.

Each pig received all eight diets in a randomized order, with different randomization being used for each pig. Each pig was given each diet for a $14 \mathrm{~d}$ period. Faeces and urine were collected for $5 \mathrm{~d}$ in each period (days 7-11). The faeces were collected twice daily on trays behind each pig, while sloping trays drained the urine into bottles containing $5 \mathrm{M}$ hydrochloric acid. All samples were frozen at $-20^{\circ}$ until analysis.

Ileal digesta were collected for $3 \mathrm{~d}$ (days 11-13 of each collection period). Samples of digesta were collected over an $8 \mathrm{~h}$ period each day at $1.5-2 \mathrm{~h}$ intervals with the total collection over $3 \mathrm{~d}$ of about $200 \mathrm{ml}$ ileal contents. All samples were bulked and stored at $-20^{\circ}$.

\section{Expt 2}

Ninety-three Large White $\times$ Landrace male pigs were weaned at $18 \mathrm{~d}$ of age and housed in tiered cages in groups of seven and offered a pelleted starter diet. At $21 \mathrm{~d}$ of age pigs were randomly allocated, one per cage, to the experimental diets.

The basal diet (Table 2) contained $7 \cdot 3 \mathrm{~g}$ lysine $/ \mathrm{kg}$. The maize starch was replaced by $\mathrm{L}$ lysine, cottonseed meal 1, cottonseed meal 2, meat meal, sunflower meal or dried skim milk to supply $8 \cdot 0,8 \cdot 7,9 \cdot 4,10 \cdot 1$ and $11 \cdot 0 \mathrm{~g}$ lysine $/ \mathrm{kg}$ diet for each supplement; a total of thirty- 
Table 2. Expt 2. Composition $(\mathrm{g} / \mathrm{kg})$ of basal diet

$\begin{array}{lr}\text { Wheat } & 539 \\ \text { Cottonseed meal 2 } & 123 \\ \text { Wheat gluten } & 90 \\ \text { Maize starch } & 200 \\ \text { Methionine } & 4 \\ \text { Calcium dihydrogen phosphate } & 36 \\ \text { Salt } & 3 \\ \text { Premix* } & 5\end{array}$

* Vitamin and mineral supplement supplying (mg/kg diet): retinol 1.5, cholecalciferol $0.025, \alpha$-tocopherol 20 , cyanocobalamin $20 \mu \mathrm{g}$, riboflavin 4 , niacin 20 , pantothenic acid 10 , biotin $0 \cdot 1$, iron 100 , copper 10 , manganese 40 , zinc 50 ; other additives $(\mathrm{mg} / \mathrm{kg}$ diet $)$ : ethoxyquin 100 , oxytetracycline 50 .

Table 3. Expt 3. Composition of diets $(\mathrm{g} / \mathrm{kg})$

\begin{tabular}{|c|c|c|c|c|c|c|c|c|}
\hline Diet no.... & 1 & 2 & 3 & 4 & 5 & 6 & 7 & 8 \\
\hline \multicolumn{9}{|l|}{ Ingredients } \\
\hline Wheat & $664 \cdot 5$ & $662 \cdot 5$ & 530 & $527 \cdot 3$ & $525 \cdot 2$ & $378 \cdot 5$ & $377 \cdot 5$ & $375 \cdot 5$ \\
\hline Soya-bean meal & 200 & 200 & - & - & -- & - & $\ldots$ & - \\
\hline Cottonseed meal 2 & - & - & 380 & 380 & 380 & - & - & - \\
\hline Sunflower meal & - & - & - & - & - & 580 & 580 & 580 \\
\hline Sunflower hulls & 95 & 95 & 50 & 50 & 50 & - & - & - \\
\hline Premix* & 2 & 2 & 2 & 2 & 2 & 2 & 2 & 2 \\
\hline $\begin{array}{l}\text { Calcium dihydrogen } \\
\text { phosphate }\end{array}$ & 33 & 33 & 33 & 33 & 33 & 33 & 33 & 33 \\
\hline Salt & 5 & 5 & 5 & 5 & 5 & 5 & 5 & 5 \\
\hline Methionine & 0.5 & 0.5 & - & - & - & $1 \cdot 5$ & $1 \cdot 5$ & 1.5 \\
\hline Lysine & - & $2 \cdot 0$ & - & $2 \cdot 7$ & $4 \cdot 8$ & - & $1 \cdot 0$ & $3 \cdot 0$ \\
\hline \multicolumn{9}{|l|}{ Chemical composition } \\
\hline Nitrogen & 30 & 30 & 35 & 35 & 36 & 39 & 39 & 40 \\
\hline Lysine & & & & & & & & \\
\hline Total & $10 \cdot 0$ & $12 \cdot 0$ & $10 \cdot 0$ & $12 \cdot 7$ & $14 \cdot 8$ & $10 \cdot 0$ & $11 \cdot 0$ & $13 \cdot 0$ \\
\hline Available & $9 \cdot 3$ & $11 \cdot 1$ & $7 \cdot 3$ & $9 \cdot 3$ & $11 \cdot 1$ & $8 \cdot 6$ & $9 \cdot 3$ & $11 \cdot 1$ \\
\hline
\end{tabular}

* Vitamin and mineral supplement supplying $(\mathrm{mg} / \mathrm{kg}$ diet): retinol 1.5, cholecalciferol 0.025, a-tocopherol 20 , cyanocobalamin $20 \mu \mathrm{g}$, riboflavin 4 , niacin 20 , pantothenic acid 10 , biotin $0 \cdot 1$, iron 100 , copper 10 , manganese 40 , zine 50 ; other additives $(\mathrm{mg} / \mathrm{kg}$ diet); ethoxyquin 100 , oxytetracycline 50 .

one diets. Three pigs were allocated to each diet, i.e. the basal diet and each level of lysine for each protein source. Diets were offered ad lib., fresh food was offered daily and wastage was weighed weekly. Water was provided by nipple drinkers. The pigs were weighed weekly.

The cages were in a controlled-environment room maintained at $26^{\circ}$. No mortalities occurred during the experiment which was of $28 \mathrm{~d}$ duration. Total faeces and urine collection were made between days 22 and 28 of the experiment. Faeces were collected on screens above sloping trays which drained the urine into bottles containing $5 \mathrm{M}-\mathrm{HCl}$.

\section{Expt 3}

Eight diets (Table 3) were prepared to contain 10 and $12 \mathrm{~g}$ lysine $/ \mathrm{kg}$ from soya-bean meal (diets 1 and 2); 10,12.7 and $14.8 \mathrm{~g}$ lysine $/ \mathrm{kg}$ from cottonseed meal no. 2 (diets 3,4 and 5); and $10,11.0$ and $13.0 \mathrm{~g}$ lysine $/ \mathrm{kg}$ from sunflower meal (diets 6, 7 and 8 ). The diets were formulated so that the total lysine content of diets 1,3 and 6 were the same. The available lysine content of diets 1,4 and 7 was $9 \cdot 3 \mathrm{~g} / \mathrm{kg}$ and that of diets 2,5 and 8 was $11 \cdot 1 \mathrm{~g} / \mathrm{kg}$. 
Table 4. Expt 4. Composition of diets $(\mathrm{g} / \mathrm{kg})$

\begin{tabular}{|c|c|c|c|c|c|c|c|c|c|c|c|}
\hline Diet no.... & 1 & 2 & 3 & 4 & 5 & 6 & 7 & 8 & 9 & 10 & 11 \\
\hline \multicolumn{12}{|l|}{ Ingredients } \\
\hline Wheat & 352 & $351 \cdot 1$ & $350 \cdot 2$ & $349 \cdot 3$ & $348 \cdot 4$ & 347.5 & 332 & 312 & 292 & 272 & 252 \\
\hline Sunflower meal & 200 & 200 & 200 & 200 & 200 & 200 & 200 & 200 & 200 & 200 & 200 \\
\hline Wheat starch & 200 & 200 & 200 & 200 & 200 & 200 & 160 & 120 & 80 & 40 & - \\
\hline Cottonseed meal 2 & - & - & - & - & - & - & 84 & 168 & 252 & 336 & 420 \\
\hline Wheat gluten & 200 & 200 & 200 & 200 & 200 & 200 & 160 & 120 & 80 & 40 & - \\
\hline Sunflower oil & - & - & - & - & - & - & 16 & 32 & 48 & 64 & 80 \\
\hline $\begin{array}{l}\text { Calcium dihydrogen } \\
\text { phosphate }\end{array}$ & 38 & 38 & 38 & 38 & 38 & 38 & 38 & 38 & 38 & 38 & 38 \\
\hline Salt & 5 & 5 & 5 & 5 & 5 & 5 & 5 & 5 & 5 & 5 & 5 \\
\hline Premix* & 5 & 5 & 5 & 5 & 5 & 5 & 5 & 5 & 5 & 5 & 5 \\
\hline Lysine & - & 0.9 & 1.8 & $2 \cdot 7$ & 3.6 & $4 \cdot 5$ & - & - & - & - & - \\
\hline \multicolumn{12}{|c|}{ Chemical composition $(\mathrm{g} / \mathrm{kg})$} \\
\hline $\begin{array}{l}\text { Crude protein } \\
(\text { nitrogen } \times 6.25)\end{array}$ & 287 & 290 & 289 & 288 & 290 & 290 & 289 & 290 & 290 & 289 & 290 \\
\hline Lysine & $7 \cdot 1$ & $8 \cdot 0$ & 8.9 & $9 \cdot 8$ & $10-7$ & 11.6 & $8 \cdot 0$ & $8 \cdot 9$ & $9 \cdot 8$ & $10 \cdot 7$ & $11 \cdot 6$ \\
\hline
\end{tabular}

* Vitamin and mineral supplement supplying (mg/kg diet): retinol 1.5 , cholecalciferol $0.025, \alpha$-tocopherol 20 , cyanocobalamin $20 \mu \mathrm{g}$, riboflavin 4 , niacin 20 , pantothenic acid 10, biotin $0 \cdot 1$, iron 100, copper 10, manganese 40 , zinc 50 : other additives $(\mathrm{mg} / \mathrm{kg}$ diet): ethoxyquin 100 , oxytetracycline 50 .

These values were calculated from the results of Expts 1 and 2, (availability of lysine taken as 0.92 for soya-bean meal, 0.73 for cottonseed meal and 0.84 for sunflower meal).

The diets were given ad lib. to seventy-two Landrace $\times$ Large White pigs from 21 to $49 \mathrm{~d}$ of age. The housing and management of the pigs was as in Expt 2. Faeces and urine were collected between days 22 and 28 of the experiment.

\section{Expt 4}

Sixty-six male Landrace $\times$ Large White pigs were given the diets shown in Table 4 , six per diet, ad lib. from 21 to $49 \mathrm{~d}$ of age. The housing and management of the pigs was as in Expt 2.

All diets in this experiment were calculated to be isonitrogenous and isoenergetic with increasing lysine content of the diets.

\section{Analytical methods}

Dry matter (DM) was determined in feed, faeces and digesta samples by drying in a fanforced air oven at $95^{\circ}$ for $24 \mathrm{~h}$. Total $\mathrm{N}$ in these samples and in urine was analysed by the Kjeldahl method (Kjel Foss; Foss-Electric, Denmark). The Yb content of the dry samples was determined by atomic absorption (Varian, USA) after digestion in perchloric and nitric acids $(1: 3, \mathrm{v} / \mathrm{v})$.

Feed and ileal samples were hydrolysed in $6 \mathrm{M}-\mathrm{HCl}$ at $105^{\circ}$ for $24 \mathrm{~h}$ before amino acid analysis by ion-exchange chromatography (Dionex, USA).

\section{Statistical methods}

The data were subjected to analysis of variance with a blocking for pigs and least significant differences $(P<0.05)$ were used to compare means statistically (Steel \& Torrie, 1980) for Expts 1 and 3 .

In Expt 2, a family of regression lines was fitted for each of weight gain, feed conversion ratio and $\mathrm{N}$ retention, with lysine being the independent variable in each case. These 


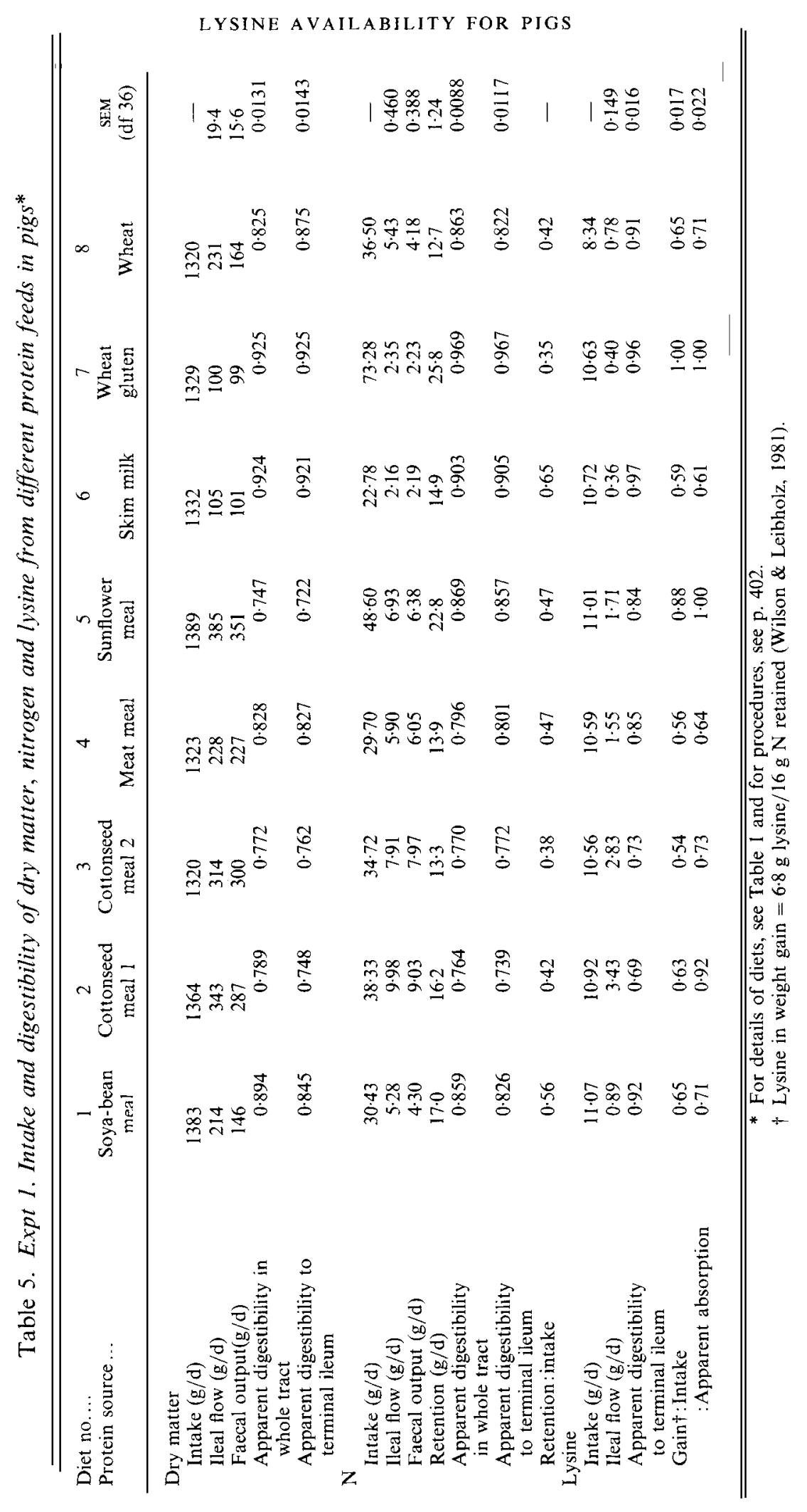


Table 6. Expt 2. Utilization of lysine (relative to free lysine) from different protein feeds by pigs*

(Mean values with their standard errors)

\begin{tabular}{lcccccc}
\hline & \multicolumn{2}{c}{ Wt gain } & \multicolumn{2}{c}{ Feed conversion ratio } & \multicolumn{2}{c}{ Nitrogen retention } \\
\hline & Mean & SF & Mean & SE & Mean & SE \\
\hline Cottonseed meal 1 & 0.68 & 0.047 & 0.67 & 0.150 & 0.65 & 0.107 \\
Cottonseed meal 2 & 0.73 & 0.050 & 0.76 & 0.158 & 0.71 & 0.115 \\
Meat meal & 0.81 & 0.047 & 0.78 & 0.165 & 0.75 & 0.123 \\
Sunflower meal & 0.86 & 0.037 & 0.86 & 0.130 & 0.79 & 0.099 \\
Skim milk & 1.00 & 0.036 & 1.05 & 0.122 & 1.01 & 0.090 \\
\hline
\end{tabular}

* For details of diets, see Table 1 and for procedures, see pp. $402-403$.

regression lines were constrained to have a common intercept, and the standard errors of the ratios of the coefficients were calculated in the usual way (Kendall \& Stuart, 1977).

In Expt 4, the linear data were treated as in Expt 2. However, where the non-linear component was significant an asymptotic regression was fitted.

\section{RESULTS}

\section{Expt 1}

The apparent digestion of DM to the terminal ileum was lowest for the sunflower-meal diet, followed by the cottonseed-meal diets and then the soya-bean meal, meat meal and wheat diets (Table 5). It was highest for the wheat-gluten and skim-milk diets. The apparent digestion of DM in the whole tract for the eight diets followed the same pattern as the DM digestibility to the ileum.

The apparent digestibility of $\mathrm{N}$ to the terminal ileum was highest for the wheat gluten followed by that for milk and then sunflower meal, soya-bean, wheat and meat meal in that order. It was lowest for the two cottonseed meals. The apparent digestibility of $\mathrm{N}$ in the whole tract was also highest for wheat gluten and then milk, followed by sunflower meal, soya-bean meal and milk. It was lower for meat meal and lowest for the cottonseed meals.

$\mathrm{N}$ retention was dependent on both the sources of $\mathrm{N}$ and the $\mathrm{N}$ intake.

The apparent digestibility of lysine to the ileum varied from 0.97 for milk to 0.69 for cottonseed meal 2 . The calculated lysine in weight gain as a ratio of absorbed lysine showed values of 1.00 for wheat gluten and sunflower meal and values between 0.59 and 0.92 for the other protein sources.

\section{Expt 2}

There was a significant linear response in weight gain, feed conversion ratio and $\mathrm{N}$ retention with increasing lysine intake for all protein sources (Table 6). The relative utilization of lysine from cottonseed meals 1 and 2 for weight gain was less than that of skim milk and sunflower meal. The values for meat meal were intermediate.

For feed conversion ratio the utilization of lysine from cottonseed meal $1(0.67)$ was significantly lower than that from skim milk (1.05). The values for the other protein sources were intermediate, but not significantly different. The standard errors of these estimates were higher than those for weight gain. The $\mathrm{N}$ retention values showed a lower availability of lysine for the cottonseed meal and meat meals than that for skim milk. The value for sunflower meal was intermediate. 
Table 7. Expt 3. Performance of pigs fed on different protein feeds formulated to compare diets with the same total lysine content or diets with the same available lysine*

\begin{tabular}{|c|c|c|c|c|c|c|c|c|c|}
\hline \multirow{2}{*}{$\begin{array}{l}\text { Protein source ... } \\
\text { Lysine }(\mathrm{g} / \mathrm{kg}) \ldots\end{array}$} & \multicolumn{2}{|c|}{ Soya-bean meal } & \multicolumn{3}{|c|}{ Cotlonseed meal 2} & \multicolumn{3}{|c|}{ Sunflower meal } & \multirow{2}{*}{$\begin{array}{c}\text { SEM } \\
(\mathrm{df} 56)\end{array}$} \\
\hline & $10 \cdot 0$ & $12 \cdot 0$ & $10 \cdot 0$ & $12 \cdot 7$ & $14 \cdot 8$ & $10 \cdot 0$ & $11 \cdot 0$ & $13 \cdot 0$ & \\
\hline Wt gain $(\mathrm{g} / \mathrm{d})$ & 323 & 396 & 136 & 270 & 374 & 199 & 227 & 358 & $19 \cdot 3$ \\
\hline Feed conversion ratio & $1 \cdot 61$ & $1 \cdot 43$ & $2 \cdot 46$ & $1 \cdot 82$ & $1 \cdot 69$ & $2 \cdot 04$ & $1 \cdot 84$ & $1 \cdot 62$ & $0 \cdot 063$ \\
\hline $\begin{array}{l}\text { Nitrogen retention } \\
(\mathrm{g} / \mathrm{d})\end{array}$ & $12 \cdot 1$ & $13 \cdot 6$ & $3 \cdot 7$ & $9 \cdot 7$ & $12 \cdot 5$ & $7 \cdot 6$ & $8 \cdot 3$ & $12 \cdot 3$ & $1 \cdot 22$ \\
\hline $\begin{array}{l}\text { Apparent digestibility } \\
\text { of dry matter }\end{array}$ & $0-81$ & 0.81 & 0.67 & 0.67 & 0.68 & $0 \cdot 73$ & $0 \cdot 74$ & $0 \cdot 73$ & 0.090 \\
\hline $\begin{array}{l}\text { Digestible dry matter } \\
\text { intake:gain }(\mathrm{g} / \mathrm{d})\end{array}$ & $1 \cdot 30$ & $1 \cdot 16$ & 1.66 & $1 \cdot 26$ & $1 \cdot 16$ & $1 \cdot 45$ & $1 \cdot 35$ & $1 \cdot 17$ & $0 \cdot 045$ \\
\hline
\end{tabular}

* For details of diets, see Table 3 and for procedures, see pp. $403 * 404$.

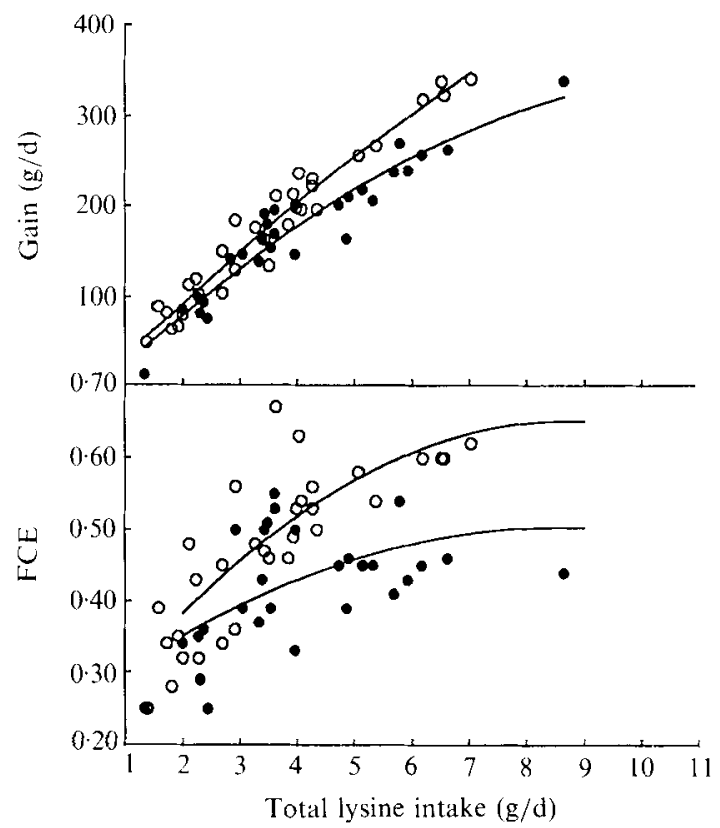

Fig. 1. Expt. 4. The weight gains and feed conversion efficiency (FCE) of pigs given an increasing amount of lysine from synthetic lysine $(\mathrm{O}-\mathrm{O})$ or cottonseed meal $2(-)$ between 21 and $49 \mathrm{~d}$ of age. For details of diets, see Table 4 and for procedures, see p. 404.

\section{Expt 3}

The weight gains increased and feed conversion ratios decreased with increasing lysine from the three sources of protein (Table 7). The feed conversion ratios were lower for soya-bean meal than for cottonseed meal or sunflower meal. However, there was a difference in the digestibility of DM for the three sources of protein. When the feed conversion ratios were calculated as digestible DM intake:gain then the values were similar for the three sources of protein at the same available lysine content. 
Table 8. Expt 4. Regression equations (SE) for the relationship between weight gain and feed conversion efficiency and lysine intake for pigs given synthetic lysine or cottonseed meal

\begin{tabular}{|c|c|c|}
\hline & Lysine source & Regression equation \\
\hline \multirow[t]{2}{*}{ Gain } & Lysine & Gain $=\frac{-10 \cdot 7}{(8 \cdot 86)}+\frac{5 \cdot 26}{(0 \cdot 23)}$ lysine intake \\
\hline & Cottonseed meal & 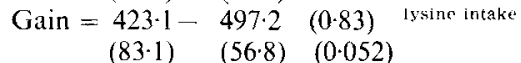 \\
\hline \multirow[t]{2}{*}{$\begin{array}{l}\text { Feed conversion } \\
\text { efficiency (FCE) }\end{array}$} & Lysine & 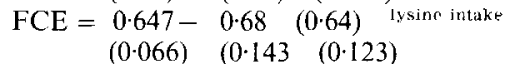 \\
\hline & Cottonseed meal & 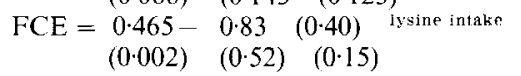 \\
\hline
\end{tabular}

\section{Expt 4}

The total lysine intake of each pig is plotted in Fig. 1, including that of the pigs given the basal diet.

With increasing lysine intake from synthetic lysine and cottonseed meals there was an increase in weight gain and feed conversion efficiency (FCE; Fig. 1).

A linear response was obtained with lysine for weight gain while the response with cottonseed meal was not linear. For feed conversion ratio both slopes were non-linear. The equations to the curves for weight gain and FCE are given in Table 8. For FCE the asymptote was higher for lysine than cottonseed meal.

\section{DISCUSSION}

There are numerous estimates in the literature of the apparent digestibility of lysine to the ileum. The apparent digestibility of lysine from soya-bean meal was found to be 0.92 in the present experiment while values of 0.79-0.88 were reported by Alimon \& Farrell (1980), Tanksley \& Knabe (1984) and Jorgensen et al. (1984). For a sunflower meal, Jorgensen et al. (1984) found the apparent digestibility of lysine to the ileum to be only 0.69 while a higher value of 0.72 was noted by Alimon \& Farrell (1980). In the present experiment the apparent digestibility of lysine in sunflower meal was 0.84 . This difference may be partially due to the lysine contents of the diets, $5.6 \mathrm{~g} / \mathrm{kg}$ in the diets of Jorgensen et al. (1984) and $8.0 \mathrm{~g} / \mathrm{kg}$ in the present experiment.

The apparent digestibility of lysine from meat meal was 0.85 in the present experiment. This is higher than the range of values of 0.58-0.67 summarized by Sauer \& Ozimek (1986) but closer to the 0.77 reported by Alimon \& Farrell (1980). This range of results is probably due to the variable quality of meat and meat-and-bone meals (Batterham et al. 1986).

For the cottonseed meals, the apparent digestibility of lysine to the ileum was 0.69 and 0.73 , which is similar to values of 0.53-0.70 summarized by Sauer \& Ozimek (1986). The digestibility of lysine in cottonseed meal is dependent on the type of cottonseed meal (Tanksley et al. 1981).

In the second experiment, the availability of lysine was estimated by linear regression in weaner pigs for five of the protein sources given in the first experiment. The availability of lysine as measured in this experiment was similar to the apparent digestibility of lysine to the ileum measured in the first experiment. This indicates that most of the absorbed lysine was utilized from these diets which were all deficient in lysine compared with the requirement of weaner pigs (Agricultural Research Council, 1981). 
The criteria used to measure availability in Expt 2 were weight gain, feed conversion ratio and $\mathrm{N}$ retention. The availability values for $\mathrm{N}$ retention tended to be lower than for the other variables, particularly for sunflower meal and the cottonseed meals. This may be explained by the higher fibre content of these protein sources, resulting in a greater gut fill.

The standard errors of the slope ratios in this second experiment were high, and much higher than those for the apparent digestibility of lysine to the ileum measured in the first experiment. Standard deviations for slope ratios of similar magnitude were reported by Batterham et al. $(1979,1984)$ with grower pigs.

In the third experiment, soya-bean meal, sunflower meal and cottonseed meal were fed at the same available lysine level as calculated from the results of the first two experiments, and it was found that the feed conversion ratio, when corrected for digestible energy intake, was similar for all three protein sources. This would suggest that the value of 0.73 for the availability of lysine in cottonseed meal 2 was reasonable. A similar experiment by Tanksley \& Knabe (1984) found that when synthetic lysine was added to cottonseed meal to give the same digestible lysine content as an all soya-bean meal diet, daily weight gain was similar. Batterham (1987) also tested his slope ratio values for cottonseed meal by feeding soya-bean meal or cottonseed meal and supplementing the cottonseed meal with synthetic lysine to the same available lysine content as the soya-bean meal diet, taking the availability of lysine in cottonseed meal as 0.30 . This resulted in similar performance of pigs on all diets. However, only one level of lysine supplement was used, and it is possible that a smaller supplement of lysine could have given the same response.

The availability of lysine in cottonseed meal was found to be $0.67-0.76$ as measured by various criteria in the second experiment and 0.61-0.80 in the studies of Leibholz (1986). With growing pigs, the availability of lysine from similar cottonseed meals was found to be considerably lower $(0 \cdot 36-0.62)$ by Batterham et al. $(1979,1984)$. An explanation is needed for the difference between these results. In all these experiments, the protein content of the diets increased with increasing lysine intake, while the digestible energy contents of the diets decreased to a variable extent depending on the source of protein.

In an attempt to clarify the situation, the fourth experiment was designed to supply increasing lysine content in the diet from synthetic lysine or cottonseed meal while maintaining a constant crude protein $(\mathrm{N} \times 6.25)$ and digestible energy content in all diets. Increasing the synthetic lysine content of the diets resulted in a linear increase in the weight gain of the pigs, but increasing the lysine content of the diets by the use of cottonseed meal resulted in a curvilinear response (Fig. 1). It is obvious that lysine alone was not the factor limiting the performance of the pigs given cottonseed meal. If the performance of the pigs given the cottonseed meal diets is compared with the performance of the pigs given the synthetic lysine diets, up to the point where there is a decrease in the cottonseed meal response, there is no difference in the slopes of the regression lines for cottonseed meal and the synthetic lysine. Thus, over this initial range, the availability of lysine from cottonseed meal was close to 1.00. After the decrease in the slope of the cottonseed-meal curve had been reached the availability of the lysine in cottonseed meal was much less than that for synthetic lysine.

The results from this experiment may help to explain the conflicting reports for the availability of lysine in cottonseed meal in the present experiment and those experiments of Batterham et al. $(1979,1984)$. The weight gain of the pigs in the experiments of Batterham et al. (1984) were 478-643 g/d while those in the present experiment regressed from 43 to $535 \mathrm{~g} / \mathrm{d}$. If the response curve for increasing amount of lysine from cottonseed meal is curvilinear as measured in Expt 4, the low availability of lysine in cottonseed meal as measured by Batterham et al. $(1979,1984)$ appears to have been measured in the upper part of the curve, while the results of Expt 2 and Leibholz (1986) cover a wider range of the 
curve resulting in a higher measured availability of lysine. In all these experiments there was a significant increase in the performance of the pigs with increasing lysine intake from cottonseed meal and synthetic lysine.

It must also be noted that the pigs in the experiments of Batterham et al. $(1979,1984)$ were fed at a restricted level while in the present experiment and in the experiment of Leibholz (1986) the pigs were fed ad lib.

The total amino acids in a feed can be reduced by incomplete digestion and absorption inherent in the feed, or due to the presence of inhibitors, or by heat damage (Eggum, 1973). The present experiments indicate that in regression experiments to determine availability of lysine it is important to use a wide range of lysine intakes as availability may not be constant and may vary with the level of lysine and other factors in the feed. On the other hand, the digestibility of lysine to the ileum appears relatively constant over a range of feeds.

This study was made possible by the support of the Australian Pig Research Council. The author also wishes to thank Mr J. McClure and Mrs R. Smith for technical assistance and Ms A. Kirby for the statistical analysis of the results.

\section{REFERENCES}

Agricultural Research Council (1981). The Nutrient Requirements of Pigs. Slough: Commonwealth Agricultural Bureaux.

Alimon, A. R. \& Farrell, D. J. (1980). Studies in pigs prepared with re-entrant cannulas. II. Disappearance of dry matter, nitrogen and amino acids from diets containing different protein sources. Australian Journal of Agricultural Research 31, 627--635.

Batterham, E. S. (1987). Availability of lysine for grower pigs. Proceedings Ist Conference of the Australasian Pig Science Association, pp. 121-123. Werribec, Australia: Pig Science Association.

Batterham, E. S., Lowe, R. F., Darnell, R. E. \& Major, E. J. (1986). Availability of lysine in meat meal, meat and bone meal and blood meal as determined by the slope-ratio assay with growing pigs, rats and chicks and by chemical techniques. British Journal of Nutrition 55, 427-440.

Batterham, E. S., Murison, R. D. \& Andersen, L. M. (1984). Availability of lysine in vegetable protein concentrates as determined by the slope-ratio assay with growing pigs and rats and by chemical techniques. British Journal of Nutrition 51, 8599.

Batterham, E. S., Murison, R. D. \& Lewis, C. E. (1979). Availability of lysine in protein concentrates as determined by the slope-ratio assay with growing pigs and rats and by chemical techniques. British Journal of Nutrition 41, 383-391.

Eggum, B. O. (1973). A study of certain factors influencing protein digestibility in rats and pigs. PhD Thesis, Copenhagen, Denmark.

Jorgensen, H., Sauer, W. C. \& Thanker, P. A. (1984). Amino acid availabilities in soybean meal, sunflower meal, fish meal and meat and bone meal fed to growing pigs. Journal of Animal Science 58, 926-934.

Kendall, M. \& Stuart, A. (1977). The Advanced Theory of Statistics vol. 1. New York: Charles Griffin \& Co.

Leibholz, J. (1986). The utilization of lysine by young pigs from nine protein concentrates compared with free lysine in young pigs fed ad lib. British Journal of Nutrition 55, 179-186.

Leibholz, J. \& Mollah, Y. (1988). Digestibility of threonine from protein concentrates for growing pigs. II. The digestibility of threonine to the terminal ileum in pigs given six protein concentrates. Australian Journal of Agricultural Research 39, 721-728.

Sauer, W. C. \& Ozimek, L. (1986). Digestibility of amino acids in swine: results and their practical applications. A Review. Livestock Production Science 15, 367-388.

Steel, R. G. D. \& Torrie, J. H. (1980). Principles and Procedures of Statistics. New York: McGraw-Hill.

Tanksley, T. D. Jr \& Knabe, D. A. (1984). Ileal digestibility of amino acids in pig feeds and their use in formulating diets. In Recent Advances in Animal Nutrition, pp. 7595 [W. Haresign and D. J. A. Cole, editors]. London: Butterworths.

Tanksley, T. D. Jr, Knabe, D. A., Purser, K., Zebrowska, T. \& Corley, J. R. (198I). Apparent digestibility of amino acids and nitrogen in three cottonseed meals and one soyabean meal. Journal of Animal Science 52, 769.777.

Wilson, R. H. \& Leibholz, J. (1981). Digestion in the pig between 7 and $35 \mathrm{~d}$ of age. 5 . The incorporation of amino acids absorbed in the small intestines into the empty-body gain of pigs given milk or soya-bean proteins. British Journal of Nutrition 45, 359-366. 